\title{
Études/Inuit/Studies
}

\section{Going Off, Growing Strong: A program to enhance individual youth and community resilience in the face of change in Nain, Nunatsiavut \\ Going Off, Growing Strong: un programme visant à augmenter la résilience des jeunes au niveau individuel et communautaire face aux changements à Nain, Nunatsiavut}

\author{
Rachel Hirsch, Chris Furgal, Christina Hackett, Tom Sheldon, Trevor Bell, \\ Dorothy Angnatok, Katie Winters et Carla Pamak
}

Volume 40, numéro 1, 2016

La santé des Inuit

Inuit health

URI : https://id.erudit.org/iderudit/1040145ar

DOI : https://doi.org/10.7202/1040145ar

\section{Aller au sommaire du numéro}

Éditeur(s)

Association Inuksiutiit Katimajiit Inc.

Centre interuniversitaire d'études et de recherches autochtones (CIÉRA)

ISSN

0701-1008 (imprimé)

1708-5268 (numérique)

Découvrir la revue

\section{Citer cet article}

Hirsch, R., Furgal, C., Hackett, C., Sheldon, T., Bell, T., Angnatok, D., Winters, K. \& Pamak, C. (2016). Going Off, Growing Strong: A program to enhance individual youth and community resilience in the face of change in Nain, Nunatsiavut. Études/Inuit/Studies, 40(1), 63-84.

https://doi.org/10.7202/1040145ar

\section{Résumé de l'article}

De nombreuses communautés autochtones redoutent de se voir dépossédées de leurs systèmes de soutiens sociaux et écologiques. En réponse aux défis que pose la santé communautaire dans de tels contextes, un certain nombre d'initiatives, telles que les programmes de mentorat pour les jeunes, ont démontré une certaine valeur sur le plan de l'accroissement des capacités adaptatives. Le programme pilote Going Off, Growing Strong ("Sortir, grandir ») procure aux jeunes à risque des opportunités de s'engager dans des activités communautaires - et enracinées dans le territoire - et de nouer des relations avec des adultes jouant le rôle de modèles à Nain, au Nunatsiavut (Labrador, Canada). Cet article représente une description interprétative de l'élaboration de ce programme novateur à partir de récits autobiographiques. Nous utilisons un cadre conceptuel développé en collaboration et se basant sur de précédents travaux pour présenter et expliquer les expériences des acteurs et la raison d'être du développement de ce programme. Les objectifs émergents de Going Off, Growing Strong sont de renforcer la résilience des jeunes de la communauté au niveau individuel et collectif par l'intermédiaire des échanges intergénérationnels de compétences et de savoirs relatifs au territoire, à la société et à la culture, en se fondant sur des appuis sociaux tels qu'un congélateur communautaire et des chasseurs-pêcheurs expérimentés. Nous avons découvert que le processus de collaboration au fil du temps avec de multiples parties prenantes pour créer ce cadre conceptuel s'est avéré important pour solidifier les objectifs de Going Off, Growing Strong et en faire ressortir une évaluation significative, propre à ce contexte, pour permettre à l'avenir d'en mesurer les impacts sur la communauté. 


\title{
Going Off, Growing Strong: A program to enhance individual youth and community resilience in the face of change in Nain, Nunatsiavut
}

\author{
Rachel Hirsch*, Chris Furgalii, Christina Hackett ${ }^{i i i}$, Tom Sheldoniv, \\ Trevor Bellv, Dorothy Angnatokvi, Katie Wintersvi, Carla Pamakvi
}

RÉSUMÉ

Going Off, Growing Strong: un programme visant à augmenter la résilience des jeunes au niveau individuel et communautaire face aux changements à Nain, Nunatsiavut

De nombreuses communautés autochtones redoutent de se voir dépossédées de leurs systèmes de soutiens sociaux et écologiques. En réponse aux défis que pose la santé communautaire dans de tels contextes, un certain nombre d'initiatives, telles que les programmes de mentorat pour les jeunes, ont démontré une certaine valeur sur le plan de l'accroissement des capacités adaptatives. Le programme pilote Going Off, Growing Strong ("Sortir, grandir") procure aux jeunes à risque des opportunités de s'engager dans des activités communautaires - et enracinées dans le territoire - et de nouer des relations avec des adultes jouant le rôle de modèles à Nain, au Nunatsiavut (Labrador, Canada). Cet article représente une description interprétative de l'élaboration de ce programme novateur à partir de récits autobiographiques. Nous utilisons un cadre conceptuel développé en collaboration et se basant sur de précédents travaux pour présenter et expliquer les expériences des acteurs et la raison d'être du développement de ce programme. Les objectifs émergents de Going Off, Growing Strong sont de renforcer la

* Social Justice Research Institute, Brock University, 1812 Sir Isaac Brock Way, St. Catharines, Ontario L2S 3A1, Canada. rhirsch@brocku.ca

ii Indigenous Environmental Studies, Trent University, 1600 West Bank Drive, Peterborough, Ontario K9J 6B8, Canada. chrisfurgal@trentu.ca

iii Faculty of Health Sciences, McMaster University, 1280 Main St. W., Hamilton, Ontario L8S 4K1, Canada. hacketc@mcmaster.ca

iv Environment and Health, Inuit Circumpolar Council Canada, 75 Albert Street, Suite 1001, Ottawa, Ontario K1P 5E7, Canada. tsheldon@inuitcircumpolar.com

v Department of Geography, Memorial University of Newfoundland, 230 Elizabeth Ave, St. John's, Newfoundland and Labrador A1B 3X9, Canada. tbell@mun.ca

vi Department of Lands and Natural Resources, Nunatsiavut Government, 25 Ikajuktauvik Road, P.O. Box 70, Nain, Newfoundland and Labrador A0P 1L0, Canada. katie_winters@ nunatsiavut.com, carla_pamak@nunatsiavut.com 
résilience des jeunes de la communauté au niveau individuel et collectif par l'intermédiaire des échanges intergénérationnels de compétences et de savoirs relatifs au territoire, à la société et à la culture, en se fondant sur des appuis sociaux tels qu'un congélateur communautaire et des chasseurs-pêcheurs expérimentés. Nous avons découvert que le processus de collaboration au fil du temps avec de multiples parties prenantes pour créer ce cadre conceptuel s'est avéré important pour solidifier les objectifs de Going Off, Growing Strong et en faire ressortir une évaluation significative, propre à ce contexte, pour permettre à l'avenir d'en mesurer les impacts sur la communauté

\section{ABSTRACT}

Going Off, Growing Strong: A program to enhance individual youth and community resilience in the face of change in Nain, Nunatsiavut

Dispossession from social and ecological support systems is a major concern for many Indigenous communities. In response to community health challenges in these settings a number of initiatives such as youth mentorship programs have shown some value in enhancing adaptive capacity. The pilot Going Off, Growing Strong program provides opportunities for at-risk youth to engage in community- and land-based activities and build relationships with positive adult role models in Nain, Nunatsiavut (Labrador, Canada). This paper offers an interpretive description drawing from autobiographical accounts of the development of this innovative program. A collaboratively developed conceptual framework, based on the literature, is used to present and explain program operator's experiences and rationale for program development. The emergent goals of Going Off, Growing Strong are to strengthen individual youth and collective community resilience through intergenerational exchange of land, social, and cultural skills and knowledge by drawing on social supports, such as a community freezer and experienced harvesters. We found that the process of collaborating over time with multiple stakeholders in creating this conceptual framework was an important one for solidifying the goals of Going Off, Growing Strong and creating context-specific, meaningful evaluation outcomes to enable future measurement of impacts on the community.

\section{Introduction}

Indigenous peoples throughout the world have been feeling the lasting impacts of historical and contemporary colonial processes through collective trauma (Crawford 2013). Dispossession and disconnection from traditional lands, governance systems, and cultural practices are associated with poor mental, physical, and spiritual health (Richmond and Ross 2009). The deterioration of family bonds and other social relationships is a recognized risk factor for mental health issues, such as depression, substance abuse, and suicide (Kral et al. 2011). A growing body of literature indicates the importance of social, cultural, and ecological connectedness to build the resilience necessary to heal and adapt to current and future change (Cameron 2015; Chansonneuve 2005; Cullen and Whiteford 2001; Kirmayer et al. 2009; Putnam 2000).

Across the Canadian North, many community members are still closely connected to and dependent on the environment. Many still hunt marine and land animals for subsistence and harvest plants and berries (Dombrowski et al. 2013). Community members speak of the healing effect and sense of freedom 
that comes with being on the land (Cunsolo Willox et al. 2013; Wolf et al. 2013). A sense of connectedness to the environment or land has often been associated with enhanced physical, mental, emotional, and spiritual wellbeing (Parlee and Furgal 2012; Richmond and Ross 2009). Many Inuit still draw strength from their relationships with each other and the land, maintaining hope that they will be able to navigate increasingly complex social-cultural environments, just as they have had to adapt to the unpredictability of their natural environments historically (Kirmayer et al. 2011).

The land may not only be a benefit but also a threat, with climate change having a major impact on the ability of communities to engage in traditional land-based activities (Parlee and Furgal 2012). A report from Statistics Canada (2011) indicates that the northern Labrador coast has experienced the highest percentage loss of sea ice over the past four decades of any region in the Canadian Arctic (73\% overall decrease in sea-ice surface area). Weather and ice conditions were reported as the most frequent reason for hunters and travellers needing search and rescue support along the coast over a 15-year period studied by Durkalec et al. (2014, 2015). Further, sea-ice users in Nain have reported increases in negative physical health impacts, such as travel-related injuries and stress, due to changing environmental conditions (ibid.).

Community freezers have been identified as a possible mechanism for coping with these impacts on food security (Furgal and Seguin 2006; Organ et al. 2014; Richmond 2009). Inuit country foods (and associated distribution programs like community freezers), however, are more than important sources of protein, minerals, and vitamins; they are invariably tied to experiences of connectivity, reciprocity, and inter-generational transmission of land skills, knowledge, and values (Ohmagari and Berkes 1997; Pearce et al. 2011). Eating healthy foods and having supportive social networks (e.g., kinship bonds or food sharing) are important for both physical and mental wellbeing. Studies indicate that social capital (indicated by the presence of trust, reciprocity, and connectivity in a community) is important for adaptation (Ford et al. 2010; Pelling and High 2005). Access to resources, such as transportation and ammunition, facilitate or restrict food sharing (Dombrowski et al. 2013). In Nain, a community freezer program encourages reciprocity by providing hunters, and now youth, with the means (bullets, gasoline) to supply the freezer so that the entire community benefits from this cultural exchange.

Going Off, Growing Strong (Aullak, Sangilivallianginnatuk, in Labrador Inuttitut) is a community freezer youth outreach program based in Nain, Nunatsiavut. It is organized around the concept of community resilience, where the focus is on how individuals adapt to stress and trauma by drawing on the social and cultural connections available to them in their community (Cameron 2015; Kirmayer et al. 2009). The program is intended to build the resilience of a group of Inuit youth in the face of widespread social, environmental, and cultural change. Its overarching goals are to: 1) enhance the mental, physical, and 
spiritual health of a group of "at-risk" youth; 2) build social connections between the youth and other community members; and 3) transmit environmental knowledge, skills, and values from experienced harvesters to youth.

In this paper, we cover the following: background to intergenerational healing initiatives in Nunatsiavut; our interpretive approach; community context; objectives of the Going Off, Growing Strong program; roles of program staff; youth activities; and relationships between program objectives, activities, and community resilience.

\section{Labrador Inuit and collective trauma}

Inuit are one of three groups designated as "Aboriginal" in the Canadian Constitution (Government of Canada 1982). This diverse group has different practices and languages and a traditional heritage that distinguishes them from First Nations and Métis. In 2011, 59,445 Inuit were living in Canada with about $75 \%$ residing in their settled land claim regions of the Canadian North: the Inuvialuit Settlement Region (Northwest Territories); Nunavut; Nunavik (northern Quebec); and Nunatsiavut (Labrador). Nunatsiavut is the first Inuit region in Canada to have achieved self-government. Its political boundaries are those of the Labrador Inuit Settlement Area, and it includes five remote Inuit communities accessible only by air, boat, or snowmobile. Its population is approximately 2,325 and is $89 \%$ Inuit. Approximately half of the population of Nunatsiavut resides in the northernmost community of Nain while another 2,300 Inuit live in Upper Lake Melville communities just south of the land claims area (Statistics Canada 2013).

Relations with early visitors, such as whalers, explorers, and early settlers, were relatively peaceful and mutually beneficial (Fitzhugh 1999). By the time Moravian missionaries established a settlement in the Nain area in 1771, Labrador Inuit regularly traded with settlers for goods, especially firearms and ammunition for hunting. However, Inuit remained relatively autonomous before Newfoundland and Labrador joined the Canadian Confederation in 1949. A negotiated self-governance system existed with elected elders as leaders who wrote community and environmental laws (ibid.). After Confederation, Labrador Inuit were classified as residents of the province and not recognized as a distinct nation, a position that effectively excluded them from the terms of the union that bound Newfoundland and Labrador to Canada (Tanner 1998).

The wellbeing of Labrador Inuit rapidly disintegrated in the postConfederation era with the implementation of a centralized liberal social welfare system (Evans 2012). Relocation was emphasized as a solution to widespread health (i.e., tuberculosis) and economic (i.e.,-unemployment) issues, as it had been elsewhere in the province (Evans 2012; Kral et al. 2009). In 1956, the province closed its trading operations at Nutak. In 1959, the Moravian mission and provincial store and services were withdrawn from Hebron, a move resulting in the forced migration of hundreds of Inuit to southern communities along the 
northern Labrador coast, including Nain, Makkovik, and Hopedale (Evans 2012). In addition to the removal of these Inuit families from their traditional hunting grounds, many of them were also separated from each other. There was thus further erosion of the familial connections and social bonds necessary for coping with widespread change. It was also around this time that the residential school system was introduced so that, for the first time in Labrador, all instruction was conducted in English and traditional cultural practices were discouraged (Younging et al. 2009).

Labrador Inuit are still adjusting to this relocation and massive upheaval in their lives. Some reconciliation came with ratification of the Labrador Inuit Land Claims Agreement in 2005, an official apology from the Government of Newfoundland and Labrador to the relocatees, and a ruling by the Royal Commission on Aboriginal Peoples that relocation constituted abuse (Crawford 2013; Younging et al. 2009). However, the impacts of this collective trauma remain and are felt acutely through intergenerational disconnection, as youth grow up in social, cultural, and ecological circumstances that differ from those of their parents and elders. Additionally, as Bombay et al. (2009) have shown, traumas experienced in one generation may be passed down to following generations through repeated patterns of learned mental, physical, or sexual abuse. Family bonds have always been essential to wellbeing and to transmission of environmental knowledge in Inuit communities (Kirmayer et al. 2009; Kral et al. 2011). The erosion of these intergenerational connections has disrupted transfer and exchange of cultural and environmental knowledge. The Going Off, Growing Strong program aims to recreate these bonds, as we will now show.

\section{Interpretive approach}

There has been much less research on youth resilience and suicide prevention in Nunatsiavut (Gojer 1992) than in other regions of the Arctic (Kral et al. 2009). Nor have programs elsewhere been reported on in sufficient detail to allow replication and critical appraisal. For these reasons, we have drawn on our personal experience, clinical expertise, meeting documentation, personal communications, and memories to interpret events and activities linked to the Going Off, Growing Strong program to provide a full account of its emergence and evolution.

The authors of this paper have been involved with the Going Off, Growing Strong program through all its stages of inception and implementation as its developers, staff, steering committee members, and research advisors. The authors include the pilot program coordinators (Nunatsiavut Government staff and Nain community members), a steering committee member (a communitybased mental health professional), an Inuk government manager, and a team of university-based research advisors (from Trent University and Memorial University). From January 2012 to March 2013, 25 meetings were held with 
program staff, steering committee members, community stakeholders, and the general public to reflect on program implementation.

We used an interpretive approach (Denzin 1999; Smart 1998) to share our experiences about the program and thus better understand and question the assumptions about how various activities are meant to achieve specific objectives. This ethnographic approach assumes that shared understandings and experiences come about through and emerge from our interactions as researchers with our participants (Hunt 2009; Thorne et al. 1997). The goal is therefore to gain access to the "web of shared meanings" that stems from residency in communities. Using Smart's (1998) approach to interpretive ethnography, we engaged with a community program, gained access to the conceptual world of our collaborators, and looked for converging perspectives to identify a larger pattern.

Through this approach, we engaged in a "thick description" (Geertz 1994) of the Going Off, Growing Strong program within its unique context and situation. We used experiences and relationships from the co-authors to augment the "thin description" of positivist descriptive observation, with meaning induced from the process and context therein (ibid.). As Geertz (1994: 229) notes, the aim of using an interpretive ethnographic approach to "thick description" is to "draw large conclusions from small, but very densely textured facts; to support broad assertions about the role of culture in the construction of collective life by engaging them exactly with complex specifics." We thus wished to know more about the roots of this program's development with a focus on the context and circumstances of its inception. This improved understanding may in turn provide insights into similar contexts.

\section{Community context leading to program development}

People in Nunatsiavut have become more insecure because of changing social, ecological, and economic circumstances of life, as explored above. However, it was predominantly concerns about country food access and the prevalence of youth suicide in the community that led to development of the Nain community freezer and youth outreach programs. The results from the 2007-2008 Inuit Health Survey for Nunatsiavut indicate that $45 \%$ of households reported being severely or moderately food insecure (Rosol et al. 2011). Country foods remain an important source of dietary protein and are still preferred by many Inuit. In the 2006 Aboriginal Peoples Survey, almost $80 \%$ of respondents from Nunatsiavut indicated that at least half of the meat and fish eaten in their household was country food (Tait 2006).

In response to ongoing concerns about access to country foods, the community and the Nunatsiavut Government introduced various food-sharing initiatives, focusing especially on elders and children. In 2006, Ulapitsaijet (a community volunteer group) purchased a regular household-sized deep freezer and placed it in a government building. Community members could freely access 
the freezer during office hours with no restrictions on use or supply (Organ et al. 2014). In 2010, a network analysis of country food distribution in Nain revealed that much of the food was supplied by a few individuals with access to a hunting vehicle (e.g., skidoo/boat) (Dombrowski et al. 2013). The current Nain community freezer program was launched to help alleviate food insecurity and reduce some of the strain on networks for country food sharing in the community.

The program was launched in March 2011 and has been led by the Environment Division of the Nunatsiavut Government and the Nain Inuit Community Government. The community freezer is now housed at the Nain Research Centre, and community members can access it on a first-come, firstserve basis during office hours with special deliveries made to elders. Local harvesters supply the community freezer on a voluntary basis; country foods are received as donations or the cost of fuel and ammunition is reimbursed. The Nain Community Freezer is also recognized as a safe space for at-risk community members, including youth, and thus as a means to improve community resilience.

Nain has had both formal and informal interventions for youth at risk. This group has perceived some of the interventions as being helpful, while noting two shortcomings: inconsistency in program delivery and lack of activities that engage youth who are disconnected from most other social and programming supports. The Nunatsiavut Department of Health and Social Development offers a program for children up to the age of 12 , and has sometimes offered drop-in services in times of community crisis (e.g., traumatic death such as suicide). The Youth Division, now partnered with the Nunatsiavut Department of Health and Social Development, has provided children and youth with specific events and culturally relevant group activities, such as sewing groups and intergenerational gatherings. The Youth Recreation Department, run by the Nain Inuit Community Government, offers youth full-day programming throughout the summer and facilitates activities and supervision at the Nain arena year-round, including sporting events and outdoor activities. ${ }^{1}$

From October to December 2011, there were six suicides of male youth aged 14 to 21 in Nain. Their peers discovered the bodies, as the suicides occurred in areas frequented by many youth. The witnesses to these traumatic deaths had relatively few adults or personal resources they could draw upon to gain comfort and cope with the trauma. Several youth stated that they, in turn, were feeling suicidal. In the wake of these suicides, feedback from youth revealed that going off (i.e., outings on the land) and learning traditional ways was something that they valued and something that at-risk youth had little access to. While no single organization in the community had the capacity to facilitate regular outings on the land, the youth had routinely described these activities as being the most enjoyable and satisfying ones. The Going Off, Growing Strong

1. These community resources existed at the inception of the program, as reported by co-authors who were living and working in Nain at that time. 
program was to be the first to specifically address the requests of the youth of Nain to go off and learn the traditional skills they needed to become connected within this Inuit community.

\section{Description of program}

The Going Off, Growing Strong program has two overall goals: improve the mental health, social connections, and coping skills of a group of youth in Nain; and enhance the intergenerational knowledge and skills transmission necessary to promote individual and, ultimately, community resilience. Program activities (e.g., harvesting trips) offer youth an opportunity to go off and grow stronger. Successful implementation is associated with the short-term (individual resilience) and long-term (collective resilience) objectives listed in Table 1.

TABLE 1. List of Going Off, Growing Strong program objectives.

1. Engage youth (especially young males who are considered "at risk") who are subject to intergenerational dislocation and disassociation from land and social networks and who are not learning the skills and gaining the experience in their local environment that their parents and elders did.

2. Through guidance from harvesters and elders, identify critical knowledge and skills required to successfully and safely "go off."

3. Increase the critical knowledge and skill-set of youth participants.

4. Improve mental health among youth participants.

5. Increase the consumption of country foods and therefore promote enhanced nutrition among youth participants.

6. Increase the sense of connectedness of youth participants within the community.

7. Improve resilience of youth to various stressors, including climate change and environmental variability.

8. Reduce youth suicide rates in the community of Nain.

9. Enhance youth engagement, behaviour and performance in school.

10. Help and enhance the long-term sustainability of food-sharing networks that exist in the community.

11. Support existing food-sharing networks in the community by increasing the amount of country foods available to those networks.

12. Enhance the adaptive capacity of Nain harvesters to environmental variability and travel hazards through expanded knowledge and improved skill sets in youth participants who are the future hunters and providers for the community. 


\section{People involved}

Going Off, Growing Strong has been planned and implemented by multiple stakeholders, including program staff, a steering committee, youth participants, and harvester volunteers.

\section{Program staff}

The core staff are affiliated with the Environment Division of the Nunatsiavut Government, and they work together to plan and implement program activities. Initially, the program was overseen predominantly by the Nain Community Freezer coordinator and the Nunatsiavut Inuit research advisor. Today, youth in the program usually contact a full-time research outreach coordinator at the Nain Research Centre. The director of the Environment Division helps manage and provide overall direction for the Going Off, Growing Strong program. Collectively, the staff are attuned to community needs, traditional knowledge, and youth engagement. They are themselves accomplished researchers and actively solicit feedback from community members and from the program steering committee.

\section{Steering committee}

Steering committee members are community representatives with expertise in experiential education, mental health and suicide prevention, youth engagement, and sustainable harvesting. The committee has helped to guide Going Off, Growing Strong towards its core goals and objectives. Committee members also advocate on behalf of youth, help select program participants, and act as key points of contact for any concerned adults and for community agencies.

\section{Research team}

An external multidisciplinary research team made up of university-based researchers has supported program planning and implementation. These research advisers have provided their knowledge and skills to assist processing of grant applications and to help guide program evaluation. In 2012, to facilitate program planning and evaluation, a postdoctoral fellow resided in Nain for 10 months. This individual was primarily responsible for discussions with program staff about the evolution and evaluation of the program and for documenting program development. All research conducted in association with the program has been reviewed and approved by provincial and Nunatsiavut Government research ethics authorities.

\section{Youth participants}

Ten at-risk youth participants (ages 14-21) were selected for this program by the steering committee, based on conversations with caregivers and service providers (Labrador-Grenfell Regional Health Authority staff, Jens Haven Memorial School, and the Nunatsiavut Department of Health and Social Development) to identify the youth most at risk and with the least access to 
healthy adults who could take them off on the land. They were considered at risk because of reported suicidal ideation and exposure to substance (or other types of) abuse in their home environments. Youth in this cohort were otherwise relatively diverse with a range of experiences (more/less time spent on the land) and different personalities (more/less outgoing). Not all the youth were attending school regularly. Many of the selected youth were not otherwise engaged in community activities and were prone to isolation. It was a collective decision by steering committee members to have an all-male cohort of youth for the pilot program, as young males in Nain have historically completed suicide at a higher rate than have females (Jong 2010). Females have been included in subsequent groups of youth participants. Agreement and consent for participation is obtained from participants, parents, and legal guardians verbally and in writing.

\section{Harvester volunteers}

Experienced and trusted harvesters are recruited to take the youth out on the land, in small and large groups, to teach them how to hunt, fish, collect firewood, navigate on the land, and prepare country foods. Harvesters were first met in early February 2012 to gauge their interest and availability. Program staff members who are most familiar with the skills and reputations of hunters in the community prepare a list of harvesters to solicit for participation in the program. Participating harvesters volunteer their time and are compensated only for the costs they incur on trips with the youth (e.g., gasoline, bullets, oil). Pairing of youth with harvesters has been one of the greatest challenges of the program, as working closely with youth requires much time from these volunteer hunters. Program members have been meeting formally and informally with harvesters to get their feedback about how the program is being operated. Near the end of the first cohort, the frequency of trips greatly increased because one harvester became a paid member of the core staff team and is now primarily responsible for youth engagement.

\section{Activities}

Program activities can be categorized broadly as land-based, communitybased, and planning-orientated. Youth, harvesters, and program staff participate in land and community-based activities while only program staff members engage in planning-oriented activities described here. The first cohort of youth started to take part in program activities in March 2012.

\section{Land-based}

Land-based activities include large and small group trips with harvesters. Each trip is unique and depends on who is available at the time and what harvesters are interested in doing with the youth. Generally, large group trips include as many of the youth as possible, multiple harvesters, several program staff, and periodically other community members, such as steering committee 
members. The length of the trips varies from day trips close to the community to multi-day trips as far as Hebron (220 km north of Nain). The trips provide youth with the opportunity to learn how to drive long distances by skidoo, to experience how their mentors navigate on land/water, and for some of the youth these types of trips provide them with "first time" experiences, such as hunting partridge or seeing a polar bear on the land. Participants in small group trips tend to be only a few youth, a single harvester, and often Nain Community Freezer staff. These smaller trips provide youth with a unique opportunity to bond more closely and learn from a particular harvester. On small trips closer to the community, youth are more likely to assist harvesters with activities, such as collecting firewood, fishing, or checking traps.

\section{Community-based}

Community-based activities aim to build connections among the youth, between youth and program staff, and between youth and other community members, such as elders. These activities have changed and evolved as the program has developed. There is a variety of activities: participating in construction projects, such as learning to build an Arctic char smokehouse or a kamutik (traditional sled towed behind a snowmobile); distributing country foods to homes in need; participating in community freezer activities, such as preparing packages of foods to be delivered; and attending research-related events, such as presentations on the youth outreach program to the community. The most common activities are group movie nights and distribution of country foods. One or more community freezer staff host movie nights several times a month. On several of these occasions, prior to screening a film, the youth are taught how to cook and prepare a meal involving wild meats (e.g., caribou pizza and Arctic char fish cakes). Commonly the movie is of a popular genre that the youth are interested in watching; however, on several occasions the youth have also watched historical or educational films about Inuit cultural heritage.

A major youth activity is now distribution of country foods to community members, especially elders, and this activity has become crucial to use and operation of the Nain Community Freezer. One of the goals of the community freezer is to ensure that all community members have sufficient access to country foods. However, there is often limited capacity to distribute country foods to community members who cannot easily access the community freezer. Staff have felt, in particular, that country foods should be distributed to elders and single parents whenever possible. The youth program has made such distribution possible. Whenever there is sufficient intake to warrant distribution of country foods, several youth help make the deliveries.

Youth have also become more involved in the general operation of the community freezer by helping to prepare (butcher/weigh/bag) wild meats for the community. Additionally, they have helped with community dinners that the community freezer staff organize to celebrate healthy country foods available 
locally. Many of these activities have emerged organically as the program has developed and as the youth have become more comfortable with program staff and harvesters. There has been an observable shift from activities that aim to engage or entertain the youth to a greater level of youth participation and assistance in general operation of the community freezer.

\section{Planning-oriented}

Documentation and reflection activities are integral to ongoing development of the Going Off, Growing Strong program. Early on, program staff and steering committee members engaged in discussions about program goals and expectations. Regular meetings have been held throughout the program operations with the youth participants, their parents, harvesters, program staff, and others. Meetings with the steering committee assist ongoing efforts to improve the program and to respond to the changing social context of the community. These meetings provide a venue for discussion and critical reflection by considering important elements of program design: program goals and objectives; operational/equipment needs; and other logistical concerns, such as staffing.

\section{Discussion}

The objectives outlined in Table 1 have evolved, maturing throughout the implementation of the program; however, they can be broadly categorized as individual or collective resilience enhancement. Objectives 1-9 focus on enhancing individual resilience and objectives 10-12 on building collective resilience. Further, the program contains two primary intervention types. The first is building "social connections" that are aimed at directly influencing individual resilience by improving the mental and physical health of youth and which indirectly influence collective resilience by enhancing community relationships (Kirmayer et al. 2009; Ledogar and Fleming 2008). The second is "intergenerational knowledge transmission," which we suggest is necessary, in addition to the presence of social supports (i.e., community freezer and youth outreach programs), to enhance collective resilience by improving the cultural connectedness of youth (Ohmagari and Berkes 1997).

While there is a broad scholarship on human resilience across many disciplines, we focus on resilience as a means to cope with adverse experiences within the context of Nain, Nunatsiavut. Discussions about how individual and collective resilience would manifest in youth participants have emerged from the process of developing the Going Off, Growing Strong program. Cameron et al. (2015) suggest that the term "resilience" in climate change dialogues is highly politicized. We adopt Cameron et al.'s exploration of resilience as annagunnarninga or "a process by which an individual, collective, or our environment has gone through great challenge or suffering but can survive" 
(ibid.: 279). In the context of Going Off, Growing Strong, resilience is focused on how building connections may help youth cope with challenges and suffering in their lives, in order to survive.

In contemporary psychology, the concept of resilience refers to an individual's ability to overcome stress and adversity. There is an emphasis in mental health research on individual strength and capacity for positive outcomes; however, typically, resilience is referenced as the inverse of vulnerability or risk (Kirmayer et al. 2011). For example, despite data limitations for some regions, such as Nunatsiavut, Oliver et al. (2012) indicate that the ratio of youth suicide among Inuit to youth suicide in the rest of Canada is higher for males ( 35 times higher) than for females (20 times higher). This type of suicide is a major source of stress and adversity in many northern communities (Kral 2012, 2013). Thus, male youth, who were considered most at risk for suicidal ideation and who lacked social supports in the community, were selected as the focus for this pilot program.

Internal and/or external factors may help reduce an individual's vulnerability to stress and anxiety in the presence of adversity. Internal factors include problem-solving skills, flexibility, and social skills. External factors include the family, the community, and broader social networks (Fleming and Ledogar 2008). Collectively, these two forms of protective factors comprise what is called "community resilience" in the literature. Community resilience can refer either to the suite of protective factors available to individuals through their socialcultural support networks or to the collective resilience of a community to stress (Kirmayer et al. 2009).

The Going Off, Growing Strong program primarily aims to enhance youth resilience by building social connections. Ledogar and Fleming (2008) developed a framework for connecting the concept of "social capital" to Indigenous youth resilience by considering four dimensions: individual social capital; collective social capital; individual resilience; and collective resilience. Putnam (2000) argues that social capital emerges from community or collective environments in the form of relatively strong or weak ties. A well-connected community (with greater social capital) can presumably better cope with adversity (Gilchrist 2000). Individuals have resilience to the extent they have equitable access to social supports or resources within a community (Richmond 2009). As such, individual resilience is related to collective or community resilience through the individual's access to social connections. Figure 1 provides an overview of our conceptual framework.

Richmond (2009) studied how various social supports can influence health outcomes in the Canadian Arctic. Social supports are the tangible and intangible qualities of an individual's ties or social connections. Over 20,000 Inuit across the Canadian Arctic reported the degree of positive interaction, presence of emotional support, presence of affection/intimacy, and tangible aids (e.g., access to country food) (ibid.). The results indicated that single men who were not able to participate in traditional hunting and gathering were least likely to feel supported in the community. This finding is consistent with our experiences and 
was the premise for launching the community freezer program to help support sharing of country food in the community.

Physical and mental wellbeing depends on eating healthy food and having supportive social networks (e.g., kinship bonds or food sharing) (ibid.). Marine animals, an important component of a traditional Inuit diet, are high in omega-3 fatty acids, which are particularly good at protecting against mental health issues, such as depression and psychological distress, among Inuit and other populations (Logan 2004; Lucas et al. 2009). Mental wellbeing is needed to take part in social networks that circulate food within many Inuit communities (Wenzel 2009). A recent study of social networks in Nain found that $55 \%$ of the population had no access to a cabin, skidoo, or boat (Dombrowski et al. 2013). The community freezer program was thus developed to promote consumption of country food by promoting community sharing. Going Off, Growing Strong is intended to increase social support by bringing young males into country food harvesting and sharing networks and by facilitating transfer of traditional ecological knowledge to youth participants.

The Going Off, Growing Strong program secondarily aims to enhance community resilience by encouraging exchange of traditional knowledge, values, and skills. Ohmagari and Berkes (1997) define the "transmission of Indigenous knowledges" as a process of exchanging cultural items, such as land skills or values, between individuals. There is no single definition of "traditional ecological knowledge," as this knowledge is rooted in the experiences and practices of people whose relationships with their natural environment have been passed down through generations (Berkes 1999). Knowledge transmission is part of a socialization process where children and youth learn to adapt to the society they are embedded within (Cristancho and Vining 2009). Some of these skills and values will remain relatively stable across generations, while others will change with evolving social, ecological, and economic contexts. For example, both Ohmagari and Berkes (1997) and Pearce et al. (2011) found higher transmission rates for modern approaches to hunting, fishing, and camping. Transfer of certain skills, such as fur preparation or weather forecasting, has decreased with the increasing availability of more convenient and modern technologies (ibid.).

Even with the evolution of traditional practices, transmission of cultural knowledge remains important for community wellbeing, cohesion, and ultimately community resilience (Cumming-Potvin and MacCallum 2010). These types of knowledge are generated through a process of mentorship whereby younger generations learn from older generations by observation and hands-on experience (Ohmagari and Berkes 1997). Traditionally, a parent or grandparent had the role of mentor; however, there is evidence of a shift towards younger generations also, or sometimes exclusively, being mentored by non-parental adults (Pearce et al. 2011). Social support by positive adult mentors enhances individual resilience by providing a buffer against risk factors, such as the absence of a kinship network (Richmond 2009; Sterrett et al. 2011). This 
mentorship, however, is only one of the social supports necessary to facilitate transmission of environmental knowledge. Also necessary is access to the land because learning is experiential and occurs in context (Ohmagari and Berkes 1997; Pearce et al. 2011; Takano 2005). An intimate relationship with traditional lands provides a connection to the past, to ancestors, and to a cohesive sense of community, thus offering a reprieve from the collective traumas of many northern communities (Takano 2005).

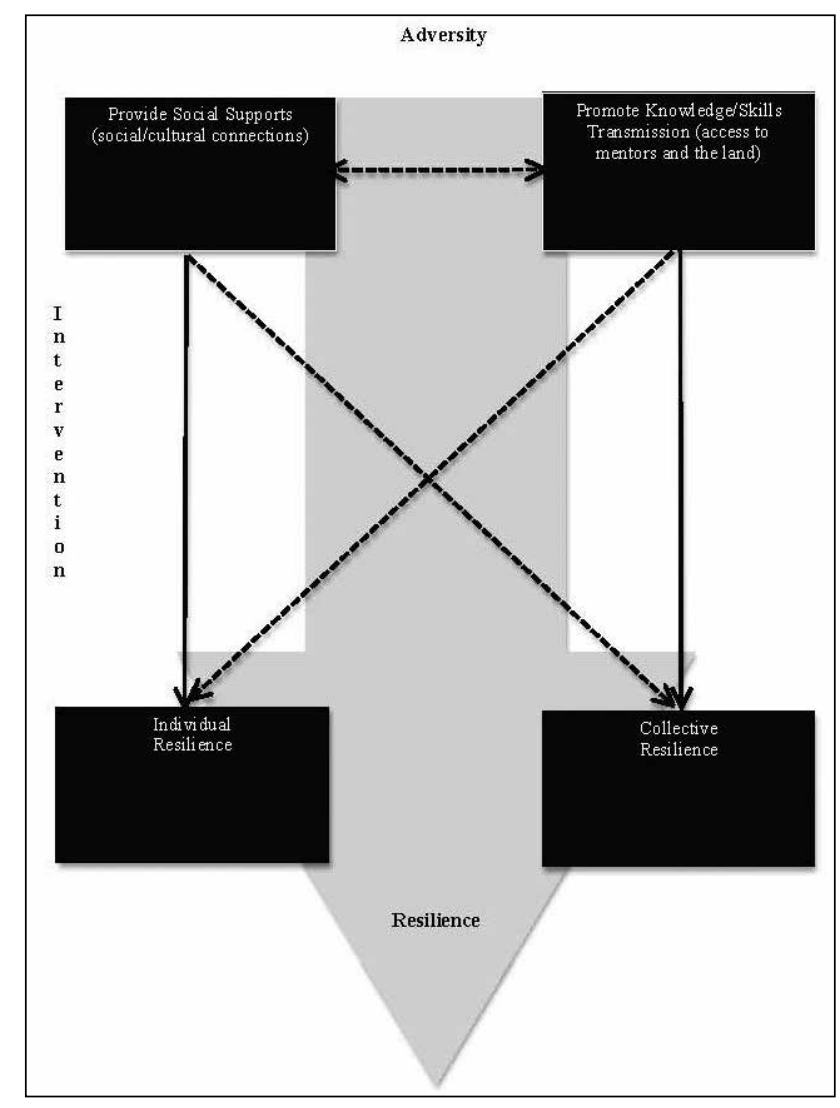

FIGURE 1. Conceptual model of Going Off, Growing Strong intervention.

Geertz's (1994) notion of "thick description" inspired development of our conceptual framework, which, in turn, has informed participatory evaluation of the Going Off, Growing Strong program. This community-based participatory research method is used to assess the "success" of a community program or policy (Lennie 2005; Papineau and Kiely 1996). Also known as "empowerment evaluation," it is a concept that speaks to self-determination in evaluative methods (Wandersman et al. 2004). Using this approach, we trained participants to conduct their own evaluations in order to build future evaluation (and 
adaptive) capacity. Multiple methods were drawn from the collaborative process of program development, and applied to the evaluation process, including stakeholder engagement, formal outcome assessment, and documentation of program activities. The evaluation team and program staff are continuing their work through an ongoing process of planning, implementing, and reflecting on the program.

\section{Conclusion}

Dispossession from social and ecological support systems is a major concern for many Indigenous communities. Several scholars have suggested that support for community freezers and youth mentorship may prove to be useful adaptation strategies. By participating in Going Off, Growing Strong program activities, Inuit male youth from Nain were given the opportunity to acquire the skills necessary to safely "go-off" and connect with harvesters, program staff, and other community members. We expected that enhancing the youth's sense of self-efficacy and belonging would improve their overall mental health and ability to cope with social, environmental, and other forms of change they are facing in the community today. Building strong individuals is the first step towards building strong communities. In an Inuit context, this includes transmission of critically important environmental knowledge, skills, and values that promote cultural connectedness so that the collective resilience of a community can emerge.

This paper expands on growing evidence for the importance of social and cultural capital as a means to enhance the resilience of Indigenous youth, especially via land-based programs for Inuit youth. We have provided an interpretive description of the Going Off, Growing Strong program by drawing on meeting notes, our personal experiences, and memories to document how we implemented the program and how it has evolved. We propose that building "social connections" improves the individual resilience (mental and physical health) of youth and that promoting "intergenerational knowledge transmission" enhances collective resilience by improving the cultural connectedness of youth. These core concepts informed a participatory evaluation of the program, thereby helping to alleviate the paucity of rigorous program evaluations in northern community settings. The rationale of the Going Off, Growing Strong program therefore provides communities with an important template for co-creating a conceptual framework and resulting outcome measures, so that they can better understand the impact of such a program on chosen outcomes.

More community-based services are needed to address mental health issues and collective trauma in Nunatsiavut and across the Canadian North. This is apparent in two ways: first, there is a need for program activities that community youth have identified as activities they wish to attend and engage in (i.e., "going off'); second, there is a need for programs that involve long-term commitment by youth participants. Our work with community youth is a starting point. We 
have shown how a multifaceted approach to relationship and skill building can help communities respond to change and adversity through individual and collective resilience.

\section{Acknowledgments}

This paper is in memory of our colleague Dorothy "Duru" Angnatok, who was central to the program and brought joy to the lives of the youth and the community. The program and the work continue as an ongoing dedication to her memory. The authors gratefully acknowledge the participants, their families, and the community of Nain, Nunatsiavut for their participation and trust in this program. The authors thank the following organizations for financial support: Health Canada, Aboriginal Affairs and Northern Development Canada, Ulapitsaijet, the Canadian Institutes for Health Research, Memorial University, and the Tasiujatsoak Trust. In-kind contributions are acknowledged from the Nunatsiavut Government, the Northern Contaminants Program, ArcticNet, Trent University, and the Nain Inuit Community Government. During the project, Rachel Hirsch worked for the Labrador Institute of Memorial University of Newfoundland in Nain, and Tom Sheldon worked for the Department of Lands and Natural Resources of the Nunatsiavut Government, likewise in Nain.

\section{References}

BERKES, Fikret

1999 Sacred ecology: Traditional ecological knowledge and resource management, Philadelphia, Routledge.

BOMBAY, Amy, Kim MATHESON and Hymie ANISMAN

2009 Intergenerational trauma: Convergence of multiple processes among First Nations peoples in Canada, Journal of Aboriginal Health, 5(3): 6-47.

CHANSONNEUVE, Deborah

2005 Reclaiming connections: Understanding residential school trauma among Aboriginal people, Ottawa, Aboriginal Healing Foundation (online at: http://epub.sub.uni -hamburg.de/epub/volltexte/2009/2895/pdf/reclaiming_connections.pdf).

CRAWFORD, Allison

2013 "The trauma experienced by generations past having an effect in their descendants": Narrative and historical trauma among Inuit in Nunavut, Canada, Transcultural Psychiatry, 51(3): 339-369.

CRISTANCHO, Sergio and Joanne VINING

2009 Perceived intergenerational differences in the transmission of Traditional Ecological Knowledge (TEK) in two Indigenous groups from Colombia and Guatemala, Culture E Psychology, 15(2): 229-254. 
CULLEN, Michelle and Harvey WHITEFORD

2001 The interrelations of social capital with health and mental health, Canberra, Government of the Commonwealth of Australia, Department of Health and Age Care, Mental Health and Special Programs Branch, National mental health strategy.

CUMMING-POTVIN, Wendy and Judith MacCALLUM

2010 Intergenerational practice: Mentoring and social capital for twenty-first century communities of practice, McGill Journal of Education, 45(2): 305-324.

CUNSOLO WILLOX, Ashlee, Sherilee HARPER, Victoria EDGE, Karen LANDMAN, Karen HOULE and James FORD

2013 The land enriches the soul: On climatic and environmental change, affect, and emotional health and well-being in Rigolet, Nunatsiavut, Canada, Emotion, Space and Society, 6: 14-24.

DENZIN, Norman

1999 Interpretive ethnography for the next century, Journal of Contemporary Ethnography, 28(5): 510-519.

EVANS, Peter

2012 Abandoned and ousted by the state: Relocations from Nutak and Hebron, 1956-1959, in David Natcher, Larry Felt and Andrea Proctor (eds), Settlement, Subsistence and Change Among the Labrador Inuit: The Nunatsiavimmiut Experience, Winnipeg, University of Manitoba Press: 85-120.

DOMBROWSKI, Kirk, Emily CHANNELL, Bilal KHAN, Joshua MOSES, and Evan MISSHULA

2013 Out on the land: Income, subsistence activities, and food sharing networks in Nain, Labrador, Journal of Anthropology, 11: doi:10.1155/2013/185048.

DURKALEC, Agata, Chris FURGAL, Martin SKINNER and Tom SHELDON

2014 Investigating environmental determinants of injury and trauma in the Canadian North, International Journal of Environmental Research and Public Health, 11: 1536-1548.

2015 Climate change influences on environment as a determinant of Indigenous health: Relationships to place, sea ice, and health in an Inuit community, Social Science and Medicine, 136-137: 17-26.

FITZHUGH, Lynne

1999 The Labradorians: Voices from the Land of Cain, St. John's, Breakwater Books Ltd.

FORD, James, Tristan PEARCE, Frank DUERDEN, Chris FURGAL and Barry SMIT

2010 Climate change policy responses for Canada's Inuit population: The importance of and opportunities for adaptation, Global Environmental Change, 20(1): 177-191.

FURGAL, Christopher and Jacinthe SEGUIN

2006 Climate change, health and vulnerability in Canadian northern Aboriginal communities, Environmental Health Perspectives, 114(12): 1964-1970.

GEERTZ, Clifford

1994 Thick description: Toward an interpretive theory of culture, in Michael Martin and Lee McIntyre (eds), Readings in the Philosophy of Social Science, Boston, MIT Press: 213-232. 
GILCHRIST, Alison

2000 The well-connected community: Networking to the edge of chaos, Community Development Journal, 35(3): 264-275.

GOJER, J.A.

1992 Providing mental health services in northern Newfoundland, Labrador: A unique challenge, Canadian Medical Association Journal/Journal de l'Association Medicale Canadienne, 147(8): 1209-1212.

\section{GOVERNMENT OF CANADA}

1982 Constitution Act, 1982, being Schedule B to the Canada Act 1982 (UK) c 11, Ottawa, Public Works and Government Services Canada.

HUNT, Matthew

2009 Strengths and challenges in the use of interpretive description: Reflections arising from a study of the moral experience of health professionals in humanitarian work, Qualitative Health Research, 19(9): 1284-1292.

JONG, Michael

2010 Suicide project report, Happy Valley-Goose Bay, Nunatsiavut Government, Department of Health and Social Development.

KIRMAYER, Laurence, Stéphane DANDENEAU, Elizabeth MARSHALL, Morgan PHILLIPS and Karla WILLIAMSON

2011 Rethinking resilience from Indigenous perspectives, Canadian Journal of Psychiatry/ Revue Canadienne de Psychiatrie, 56(2): 84-91.

KIRMAYER, Laurence, Megha SEHDEV, Rob WHITLEY, Stephanie DANDENEAU and Colette ISAAC

2009 Community resilience: Models, metaphors and measures, Journal of Aboriginal Health, 5: 62-117.

KRAL, Michael

2012 Postcolonial suicide among Inuit in Arctic Canada, Culture, Medicine and Psychiatry, 36(2): 326-326.

2013 "The weight on our shoulders is too much, and we are falling": Suicide among Inuit male youth in Nunavut, Canada, Medical Anthropology Quarterly, 27(1): 63-83.

KRAL, Michael, Lori IDLOUT, Bruce MINORE, Ronald DYCK and Laurence KIRMAYER

2011 Unikkaartuit: Meanings of well-being, unhappiness, health, and community change among Inuit in Nunavut, Canada, American Journal of Community Psychology, 48(34): $426-438$.

KRAL, Michael, Patricia WIEBE, Kari NISBET, Catherine DALLAS, Looee OKALIK, Nubiya ENUARAQ and James CINOTTA

2009 Canadian Inuit community engagement in suicide prevention, International Journal of Circumpolar Health, 68(3): 292-308.

LEDOGAR, Robert and John FLEMING

2008 Social capital and resilience: A review of concepts and selected literature relevant to Aboriginal youth resilience research, Pimatisiwin: A Journal of Aboriginal and Indigenous Community Health, 6(2): 25-46. 
LENNIE, June

2005 An evaluation capacity-building process for sustainable community IT initiatives: Empowering and disempowering impacts, Evaluation, 11(4): 390-414.

LOGAN, Alan

2004 Omega-3 fatty acids and major depression: A primer for the mental health professional, Lipids in Health and Disease, 3: 25, doi:10.1186/1476-511X-3-25.

LUCAS, Michel, Eric DEWAILLY, Carole BLANCHET, Suzanne GINGRAS, and Bruce HOLUB 2009 Plasma omega-3 and psychological distress among Nunavik Inuit (Canada), Psychiatry Research, 167(3): 266-278.

OHMAGARI, Kayo and Fikret BERKES

1997 Transmission of Indigenous knowledge and bush skills among the western James Bay Cree women of subarctic Canada, Human Ecology, 25(2): 197-222.

OLIVER, Lisa, Paul PETERS and Dafna KOHEN

2012 Mortality rates among children and teenagers living in Inuit Nunangat: 1994 to 2008, Statistics Canada Health Reports, 23(3): 7.

ORGAN, Jennifer, Heather CASTLEDEN, Chris FURGAL, Tom SHELDON and Catherine HART 2014 Contemporary programs in support of traditional ways: Inuit perspectives on community freezers as a mechanism to alleviate pressures on wild food access in Nain, Nunatsiavut, Health and Place, 30: 251-259

PAPINEAU, Danielle and Margaret KIELY

1996 Participatory evaluation in a community organization: Fostering stakeholder empowerment and utilization, Evaluation and Program Planning, 19(1), 79-93.

PARLEE, Brenda and Chris FURGAL

2012 Well-being and environmental change in the Arctic: A synthesis of selected research from Canada's International Polar Year Program, Climatic Change, 115(1): 13-34.

PEARCE, Tristan, Harold WRIGHT, Roland NOTAINA, Adam KUDLAK, Barry SMIT, James FORD and Christopher FURGAL

2011 Transmission of environmental knowledge and land skills among Inuit men in Ulukhaktok, Northwest Territories, Canada, Human Ecology, 39(3): 271-288.

PELLING, Mark and Chris HIGH

2005 Understanding adaptation: What can social capital offer assessments of adaptive capacity?, Global Environmental Change, 15(4): 308-319.

PUTNAM, Robert

2000 Bowling alone: The collapse and revival of American Community, New York, Simon and Schuster.

RICHMOND, Chantelle

2009 The social determinants of Inuit health: A focus on social support in the Canadian Arctic, International Journal of Circumpolar Health, 68(5): 471-487.

RICHMOND, Chantelle and Nancy ROSS

2009 The determinants of First Nation and Inuit health: A critical population health approach, Health \& Place, 15(2): 403-411. 
ROSOL, Renata, Catherine HUET and Michele WOOD

2011 Prevalence of affirmative responses to questions of food insecurity: International Polar Year Inuit Health Survey, 2007-2008, International Journal of Circumpolar Health, 70(5): 488-497.

SMART, Graham

1998 Mapping conceptual worlds: Using interpretive ethnography to explore knowledgemaking in a professional community, Journal of Business Communication, 35(1): 111-127.

\section{STATISTICS CANADA}

2011 EnviroStats: Table 2 - Change in Area Covered by Sea Ice during Summer from 1968 to 2010, Ottawa, Statistics Canada (online at: http://www.statcan.gc.ca/pub/16002-x/2011004/t006-eng.htm).

2013 National household survey, 2011: Aboriginal peoples in Canada (First Nations People, Métis and Inuit) Ottawa, Statistics Canada, doi:978-1-100-22203-5.

STERRETT, Emma, Deborah JONES, Laura MCKEE and Carlye KINCAID

2011 Supportive non-parental adults and adolescent psychosocial functioning: Using social support as a theoretical framework, American Journal of Community Psychology, 48(3-4): 284-295.

TAIT, Heather

2006 Aboriginal peoples survey, 2006: Inuit health and social conditions, Ottawa, Statistics Canada, doi:89-637-X no. 001.

TAKANO, Takako

2005 Connections with the land: Land-skills courses in Igloolik, Nunavut, Ethnography, 6(4): 463-486.

TANNER, Adrian

1998 The Aboriginal peoples of Newfoundland and Labrador and Confederation, Newfoundland and Labrador Studies, 14(2): 238-252.

THORNE, Sally, Sheryl REIMER KIRKHAM and Janet MacDONALD-EMES

1997 Interpretive description: A noncategorical qualitative alternative for developing nursing knowledge, Research in Nursing \& Health, 20(2): 169-177.

WANDERSMAN, Abraham, Dana KEENER, Jessica SNELL-JOHNS, Robin MILLER, Paul FLASPOHLER, Melanie LIVET-DYE, Julia MENDEZ, Thomas BEHRENS, Barbara BOLSON and LaVome ROBINSON

2004 Empowerment evaluation: Principles and action, in Leonard Jason, Christopher Keys, Yolanda Suarez-Balcazar, Renee Taylor and Margaret Davis (eds), Participatory community research: Theories and methods in action, Washington, American Psychological Association: 139-156.

WENZEL, George

2009 Canadian Inuit subsistence and ecological instability: If the climate changes, must the Inuit?, Polar Research, 2(1): 89-99. 
84 | Rachel Hirsch et al.

WOLF, Johanna, Ilana ALLICE and Trevor BELL

2013 Values, climate change, and implications for adaptation: Evidence from two communities in Labrador, Canada, Global Environmental Change, 23(2): 548-562.

YOUNGING, Gregory, Jonathan DEWAR and Mike DeGAGNÉ (eds)

2009 Response, responsibility, and renewal: Canada's truth and reconciliation journey, Ottawa, Aboriginal Healing Foundation, Aboriginal Healing Foundation Research Series. 